\title{
Model of the hysteresis loop of soft-magnetic amorphous alloys with the usage of a modified linear fractional function
}

\author{
V. Yu. Vvedenskiy, E. N. Tokmakova ${ }^{\dagger}$ \\ †katrin.2027@yandex.ru
}

National University of Science and Technology “MISiS”, Moscow, 119049, Russia

Modelling the hysteresis loop is necessary when creating various electrical devices containing ferromagnetic elements, or when studying the physical processes occurring in these elements. The model of the hysteresis loop is optimal for use when, firstly, it provides a description of the loop branches with sufficient accuracy, and, secondly, the parameters of which have a clear physical meaning, and the behavior of which can be predicted, which is typical for interpolation models. The paper proposes an interpolation model of the hysteresis loop, which ensures the coincidence of theoretical and experimental curves at the tops of the hysteresis loop, and at the points of residual induction and coercive force. To describe the descending and ascending branches of the hysteresis loop, a modified linear fractional function was used to describe the contribution to the induction of irreversible magnetization reversal processes, and the Langevin function for the reversible contribution. The adequacy of the model has been established by comparing the calculated and experimental data obtained in low and high magnetic fields, using the example of three amorphous soft magnetic alloys - based on iron, cobalt and iron-cobalt. The model was verified using an analysis of variance based on calculating the residual variance of magnetic induction and the Fisher criterion. The resulting model provides a sufficiently high-quality approximation of the values of magnetic induction with an error not exceeding the measurement error, and its application doesn't require complex calculations or the development of a special computer program.

Keywords: simulation, hysteresis loop, linear fractional function, amorphous soft magnetic alloy, ferromagnetic.

УДК: 537.622

\section{Модель петли гистерезиса магнитомягких аморфных сплавов с использованием модифицированной дробно-линейной функции}

\author{
Введенский В. Ю., Токмакова Е.Н. ${ }^{\dagger}$ \\ Национальный исследовательский технологический университет «МИСиС», Москва, 119049, Россия
}

\begin{abstract}
Моделирование петли гистерезиса необходимо при создании различных электротехнических устройств, содержащих ферромагнитные элементы, а также при исследовании физических процессов, протекающих в этих элементах. Оптимальной для использования можно считать ту модель петли гистерезиса, которая, во-первых, обеспечивает описание ветвей петли с достаточной точностью, а, во-вторых, параметры которой имеют ясный физический смысл, и поведение которых может быть предсказано, что характерно для интерполяционных моделей. В работе предложена интерполяционная модель петли гистерезиса, обеспечивающая совпадение теоретических и экспериментальных кривых в вершинах петли гистерезиса, а также в точках остаточной индукции и коэрцитивной силы. Для описания нисходящей и восходящей ветвей петли гистерезиса использована модифицированная дробно-линейная функция для вклада в индукцию необратимых процессов перемагничивания и функция Ланжевена для обратимого вклада. Установлена адекватность модели путем сравнения расчетных и экспериментальных данных, полученных в магнитных полях с малой и большой напряженностью, на примере трёх аморфных магнитомягких сплавов на основе железа, кобальта и железо-кобальта. Проверка адекватности модели осуществлялась с использованием дисперсионного анализа, основанного на расчете остаточной дисперсии магнитной индукции и вычислении критерия Фишера. Полученная модель обеспечивает достаточно качественную аппроксимацию значений магнитной индукции с погрешностью, не превышающей погрешность измерений, а её применение не требует сложных расчётов или разработки специальной компьютерной программы.
\end{abstract}

Ключевые слова: моделирование, петля гистерезиса, дробно-линейная функция, аморфный магнитомягкий сплав, ферромагнетик. 


\section{Introduction}

The phenomenon of hysteresis is well-known in Physics, technology, Economics and other branches of science. In Physics, hysteresis dependences are found for various materials with a nonlinear response to external action, in particular, for ferromagnets.

The magnetic hysteresis loop (HL) is one of the main characteristics of ferro- and ferrimagnets that are used in various electrical products, such as rotors and stators of electric motors and generators, transformers, magnetic shields, magnetic modulators, magnetic sensors for various purposes [1].

Simulation of the HL is intended to find a way to compactly store information about the magnetization reversal. The resulting models can be used by designers to calculate the designed devices, physicists - to study the features of magnetization reversal processes, materials scientists - to predict the magnetic properties under various effects on the material. Requirements for the accuracy of description, universality (possibility of using for a wide range of magnetization reversal fields), and a small number of parameters used can be imposed on the HL model. The optimal model for forecasting can be considered a model, the parameters of which have a clear physical meaning, and the behavior of which can be predicted.

At the moment, there is a wide variety of mathematical models of HL [2-6], many of which are either not very accurate or require complex calculations (solving nonlinear differential equations, introducing nonlinear hysteresis terms into linear equations, etc.). The highly accurate Preisach model [8] described in [1-6] and the Jiles-Atherton model [9] are arranged in a similar way. The disadvantages of these models include the complexity of the procedure for identifying parameters and the difficulty of their interpretation.

The parameters of interpolation models have a clear meaning and a predictable change under impacts, for example, during thermal (thermomagnetic) treatment. These parameters coincide with the traditionally measured parameters of the $\mathrm{HL}$, for example, the residual induction $B_{r}$ and the coercive force $H_{c}$. So, in [10], a linear fractional function of the form $B(H)=(a H+b) /(c H+d)$ was used to describe the back of the $\mathrm{HL}$ (the dependence of the induction $B$ on the magnetic field $H$ in the second quadrant), where the coefficients $a, b, c, d$ were selected from the conditions for the passage of the curve $B(H)$ through the points of residual induction, coercive force, and points of maximum energy product. The drawback of this formula is the absence of an inflection on the $B(H)$ curve and, as a consequence, limited applicability for describing the hysteresis loop only in the second quadrant. This drawback was corrected in the model of Chan et al. [11] by modifying the linear fractional function by introducing the modulus fraction $\left|H+H_{c}\right|$ into the denominator. For a symmetric limiting hysteresis loop with respect to magnetization, the expression proposed in [11] can be given the form of Eq. (1).

$$
M_{1}(H)=M_{s} \frac{H+H_{c}}{\left|H+H_{c}\right|+H_{c}\left(\frac{M_{s}}{M_{r}}-1\right)},
$$

where $M_{1}$ is the magnetization for the downward (upper) branch of the HL, $M_{s}$ is the saturation magnetization. The nodes of the hysteresis loop, as well as the points of remanent magnetization and coercive force are used as interpolation nodes. The value of $M_{1}$ in a large field tends to $M_{s}$, in a zero field it is equal to the remanent magnetization, $M_{1}(0)=M_{r}$, at the point of the coercive force it is equal to zero, $M_{1}\left(-H_{c}\right)=0$.

Analysis shows that Eq. (1) describes only the irreversible component of the magnetization: the value of $M_{1}$ turns to 0 if the remanent magnetization is 0 . Therefore, in [12] it was proposed to supplement the Chan model by taking into account the reversible component.

The aim of this work was to study the advantages and eliminate the disadvantages of the previously proposed HL model [12], based on the interpolation of the descending and ascending branches of the HL by a modified linear fractional function with the addition of a reversible contribution to the magnetization, as well as checking the adequacy of the obtained modification of this model.

\section{Materials and methods}

To check the adequacy of the created model for comparison, the results of measurements of the static hysteresis loop were used. Comparison of calculations and experiments was carried out for representatives of three groups of amorphous soft magnetic alloys: an iron-based alloy of the nominal composition $\mathrm{Fe}_{77} \mathrm{Ni}_{1} \mathrm{Si}_{9} \mathrm{~B}_{13}$, an alloy based on cobalt with the composition $\mathrm{Co}_{68} \mathrm{Cr}_{4} \mathrm{Fe}_{4} \mathrm{Si}_{13} \mathrm{~B}_{11}$, as well as an alloy based on Fe-Co with the composition $\mathrm{Fe}_{56} \mathrm{Co}_{25} \mathrm{~B}_{14} \mathrm{Si}_{5}$. In the formulas for the chemical composition of alloys, the numbers represent the values of the atomic fractions of a chemical element, expressed as a percentage. For magnetic measurements, we used ring samples obtained by winding an amorphous ribbon onto a cylindrical quartz mandrel. The amorphous ribbons were in their original state after spinning the melt without any heat treatment. The average diameters of the samples from the three alloys indicated above were $15.7,16.3$, and $17.3 \mathrm{~mm}$, respectively. Measurements of the static magnetic characteristics of the samples were carried out by the induction-pulse method on an automated MK-3E magnetometer. To check the adequacy of the model, an analysis of variance was used based on the calculation of the residual variance of the magnetic induction $S_{r}^{2}$ (the variance of the difference between the experimental and theoretical values) and the calculation of the Fisher criterion $F$, which is equal to the ratio of the total variance to the residual variance.

\section{Model description}

If the Chan model (Eq. (1)) is used to simulate the hysteresis loop, the experimental points fall on the calculated curve only in low fields, where irreversible magnetization reversal occurs. In this case, the model is unsuitable in high fields, which was established in [12]. The situation is corrected by the Chan model improved in the same work [12], which is basic in this study, and in which the magnetization is separated into an irreversible component $M_{1 \text { irr }}$ and a reversible component $M_{1 \text { rev }}$. The basic model refers to interpolation models, and should ensure the passage of the theoretical curve through 3 points: the top of the HL, the points of residual induction and coercive force. 
For the irreversible component of the magnetization $M_{1 i r r}$ Eq. (1) was used, which is a fraction, in the numerator and denominator of which there are linear expressions for the magnetic field strength, multiplying it by the parameter $K_{s}=B_{r} / B_{s}$, which is the value of the volume fraction of the material in which the magnetization reversal is irreversible, by displacing the domain boundaries [13].

The reversible component of the magnetization $M_{1 r e v}$, which is formed mainly due to the rotation of the magnetization, was approximated by the Langevin function $L(x)=\operatorname{cth} x-1 / x$, where $x=H / H_{r e v}$, where $H_{r e v}$ is the characteristic field of the reversible magnetization process. The Langevin function is multiplied by $\left(1-K_{s}\right)$, assuming that due to a reversible process, a change in magnetization occurs in the area of the material with a volume fraction of $\left(1-K_{s}\right)$ remaining after irreversible magnetization reversal.

Then the expression for the magnetization of an arbitrary point on the descending and ascending branches of the hysteresis loop is the sum of $M_{1 \text { irr }}$ and $M_{1 \text { rev }}$. Passing from the magnetization $M_{1}$ to the induction $B_{1}\left(B_{1}=\mu_{0}\left(H+M_{1}\right)\right)$ and using the absolute values of $H$ instead of the algebraic values of the field strength, expressions for the induction of an arbitrary point on the descending and ascending branches of the hysteresis loop were obtained (Eq. (2) and (3), respectively).

$$
\begin{aligned}
& B_{1}(H)= \mu_{0} H+B_{r} \frac{H+H_{c}}{\left|H+H_{c}\right|+H_{c}\left(\frac{B_{m}}{B_{r}}-1\right)}+ \\
&+\left(1-K_{s}\right) B_{s}\left[\operatorname{cth}\left(\frac{H}{H_{r e v}}\right)-\frac{H_{r e v}}{H}\right], \\
& B_{2}(H)=\mu_{0} H+B_{r} \frac{H-H_{c}}{\left|H-H_{c}\right|+H_{c}\left(\frac{B_{m}}{B_{r}}-1\right)}+ \\
&+\left(1-K_{s}\right) B_{s}\left[\operatorname{cth}\left(\frac{H}{H_{r e v}}\right)-\frac{H_{r e v}}{H}\right],
\end{aligned}
$$

where $\mu_{0}$ is the magnetic constant, $\mathrm{H} / \mathrm{m} ; \mathrm{H}-$ magnetic field strength, $\mathrm{A} / \mathrm{m} ; B_{r}$ - residual induction, $\mathrm{T} ; B_{s}$ - saturation induction, $\mathrm{T} ; B_{m}-$ maximum induction, $\mathrm{T} ; H_{c}-$ coercive force, $\mathrm{A} / \mathrm{m} ; H_{\text {rev }}$ - adjustable parameter, which is the characteristic field of the reversible magnetization process, $\mathrm{A} / \mathrm{m} ; K_{s}-$ squareness coefficient, which was interpreted as the value of the volume fraction of the material in which the magnetization reversal is carried out by an irreversible displacement of the domain boundaries.

The model parameter $B_{s}$ was fitted and varied so that the value of $B_{800}$ was as close as possible to the value of the maximum induction $B_{m}$ obtained from the experiment.

Fig. 1 shows the curves obtained using the model [12].

On the whole, the course of the theoretical curves quite well repeats the course of the experimental ones, and the branches of the hysteresis loops converge at the ends, however, the residual dispersion of the values of the magnetic induction $S_{r}^{2}=0.02 \mathrm{~T}^{2}$ is quite large. A serious drawback of the model, indicating its non-universality, is that the branches of the hysteresis loop do not pass through the residual induction point.

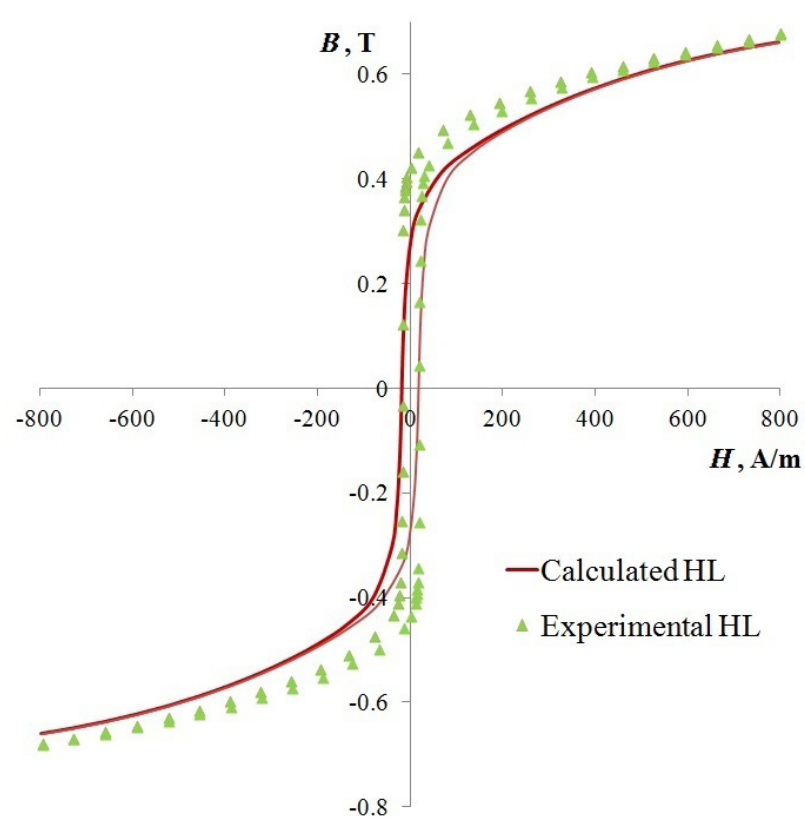

Fig. 1. (Color online) Experimental and obtained using the model [12] of the hysteresis loop at $H_{m}=800 \mathrm{~A} / \mathrm{m}$ and $K_{s}=0.63$ for alloy $\mathrm{Fe}_{56} \mathrm{Co}_{25} \mathrm{~B}_{14} \mathrm{Si}_{5}$.

This was eliminated in this article using the following formulas (Eq. (4) for the downward branch of the HL and Eq. (5) for the upward branch of the HL).

$$
\begin{aligned}
B_{1}(H) & =\mu_{0} H+B_{m 1} \frac{H+H_{c}}{\left|H+H_{c}\right|+H_{c}\left(\frac{B_{m 1}}{B_{r}}-1\right)}+ \\
& +\left(1-\frac{B_{r}}{B_{m 2}}\right) B_{m 2}\left[\operatorname{cth}\left(\frac{H}{H_{r e v}}\right)-\frac{H_{r e v}}{H}\right], \\
B_{2}(H) & =\mu_{0} H+B_{m 1} \frac{H-H_{c}}{\left|H-H_{c}\right|+H_{c}\left(\frac{B_{m 1}}{B_{r}}-1\right)}+ \\
& +\left(1-\frac{B_{r}}{B_{m 2}}\right) B_{m 2}\left[\operatorname{cth}\left(\frac{H}{H_{r e v}}\right)-\frac{H_{r e v}}{H}\right] .
\end{aligned}
$$

Two adjustable parameters were added to the calculation formula: $B_{m 1}$ and $B_{m 2}$, which, together with the previously introduced parameter $H_{r e v}$, were selected so that the maximum induction value specified from the experiment coincides with the calculated $B_{m}\left(B_{800}\right.$ in the case of measurements in the maximum field $H_{m}=800 \mathrm{~A} / \mathrm{m}$ ), and the residual dispersion of the values of the magnetic induction was minimal. In this case, the parameters $B_{m 1}$ and $B_{m 2}$ have the following physical meaning: $B_{m 1}$ is the maximum (for the particular hysteresis loop under consideration) induction in the case of the existence of only an irreversible contribution to the induction, and $B_{m 2}$ is the maximum induction in the case of magnetization only by the reversible mechanism. When simulating the hysteresis loop, the parameters $B_{r}$ and $H_{c}$ remained constant and were set from the experimental data. 


\section{Checking the adequacy of the resulting model}

The adequacy of the model was checked on amorphous alloys of various compositions by comparing the curves of the branches of the private and limiting hysteresis loop predicted by it with experimental data obtained in magnetic fields with strengths $H_{m}=100$ and $800 \mathrm{~A} / \mathrm{m}$.

HL-modelling was carried out using Eqs. (4) and (5), the parameters of which for different alloys are shown in Table 1. The resulting curves are shown in Figs. $2-4$.

The procedure of varying the adjustable parameters continued until the value $B_{800}$ became closest to the value $B_{m}$ set from the experiment and the residual dispersion of the values of the magnetic induction was minimal, which was achieved with the model parameters indicated in Table 1.

From Figs. $2-4$ it can be seen that the shape of the loops calculated using the model corresponds to the experimental data. The statistical characteristics of the obtained model dependencies are presented in Table 2.

In the case of HL-modelling for all alloys the residual dispersion of the values of the magnetic induction $S_{r}^{2}$ turned out to be very small, and the coefficient of determination $R^{2}$ was almost 1 . Finally, the applicability of the model was proved using Fisher's criterion, the value of which turned

Table 1. Parameters of the used HL model for the amorphous alloys.

\begin{tabular}{|c|c|c|c|c|c|c|}
\hline Alloy & $H_{m}, \mathrm{~A} / \mathrm{m}$ & $B_{r}, \mathrm{~T}$ & $H_{c}, \mathrm{~A} / \mathrm{m}$ & $H_{r e v}, \mathrm{~A} / \mathrm{m}$ & $B_{m 1}, \mathrm{~T}$ & $B_{m 2}, \mathrm{~T}$ \\
\hline \multirow{2}{*}{$\mathrm{Fe}_{56} \mathrm{Co}_{25} \mathrm{~B}_{14} \mathrm{Si}_{5}$} & 100 & 0.411 & 18.781 & 235 & 0.44 & 0.78 \\
\cline { 2 - 7 } & 800 & 0.4191 & 22.074 & 240 & 0.44 & 0.69 \\
\hline \multirow{2}{*}{$\mathrm{Fe}_{77} \mathrm{Ni}_{1} \mathrm{Si}_{9} \mathrm{~B}_{13}$} & 100 & 0.227 & 17.686 & 240 & 0.3 & 0.8 \\
\cline { 2 - 7 } & 800 & 0.382 & 23.583 & 300 & 0.47 & 0.46 \\
$\mathrm{Co}_{68} \mathrm{Cr}_{4} \mathrm{Fe}_{4} \mathrm{Si}_{13} \mathrm{~B}_{11}$ & 100 & 0.349 & 1.325 & 230 & 0.38 & 0.59 \\
\cline { 2 - 7 } & 800 & 0.334 & 3.150 & 240 & 0.36 & 0.46 \\
\hline
\end{tabular}

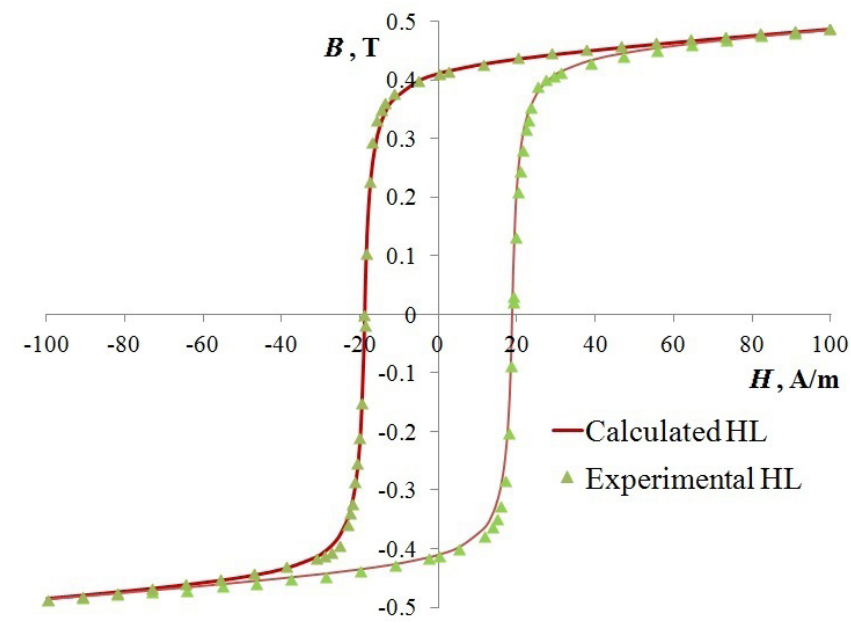

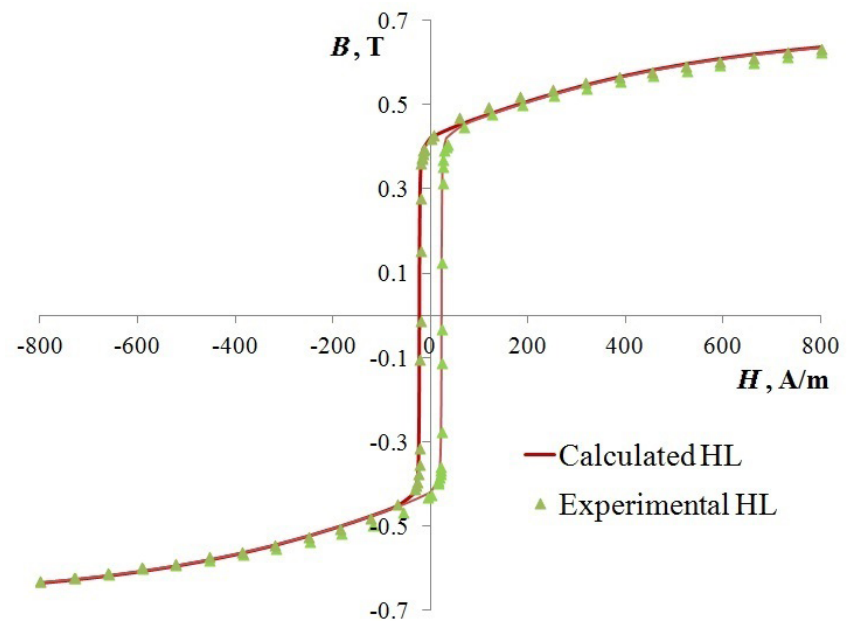

$\mathrm{b}$

Fig. 2. (Color online) Experimental and obtained by modelling the hysteresis loop of the amorphous $\mathrm{Fe}_{56} \mathrm{Co}_{25} \mathrm{~B}_{14} \mathrm{Si}_{5}$ alloy in a field of $100 \mathrm{~A} / \mathrm{m}(\mathrm{a})$ and $800 \mathrm{~A} / \mathrm{m}(\mathrm{b})$.

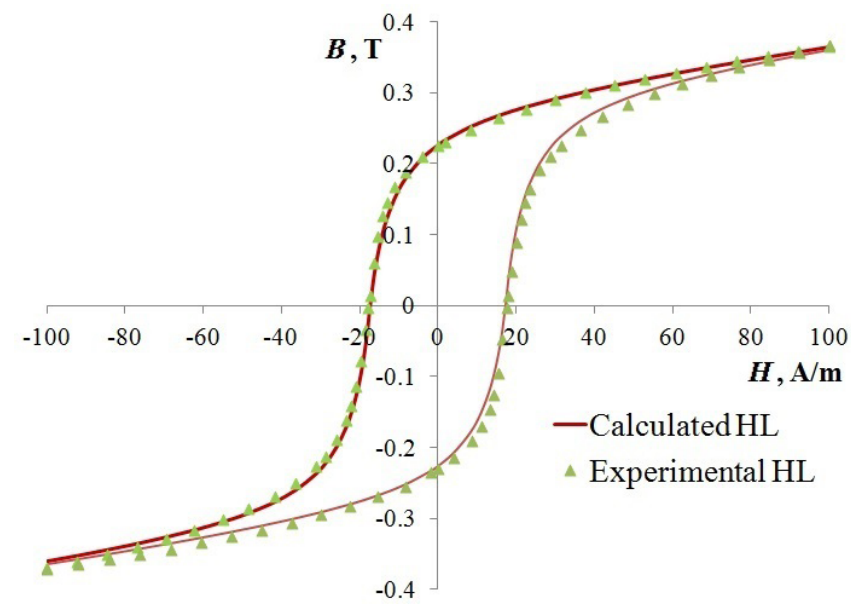

a

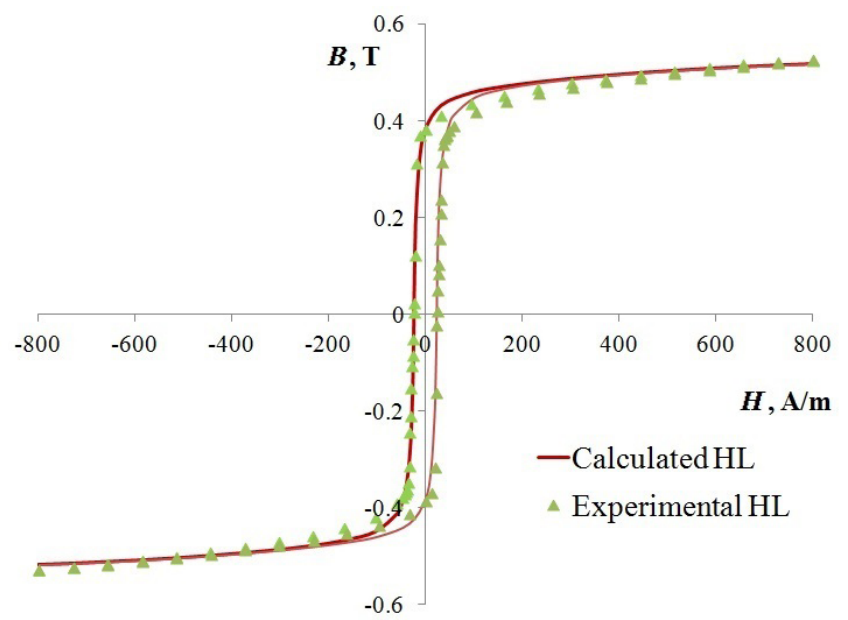

$\mathrm{b}$

Fig. 3. (Color online) Experimental and obtained by modelling the hysteresis loop of the amorphous $\mathrm{Fe}_{77} \mathrm{Ni}_{1} \mathrm{Si}_{9} \mathrm{~B}_{13}$ alloy in a field of $100 \mathrm{~A} / \mathrm{m}(\mathrm{a})$ and $800 \mathrm{~A} / \mathrm{m}(\mathrm{b})$. 

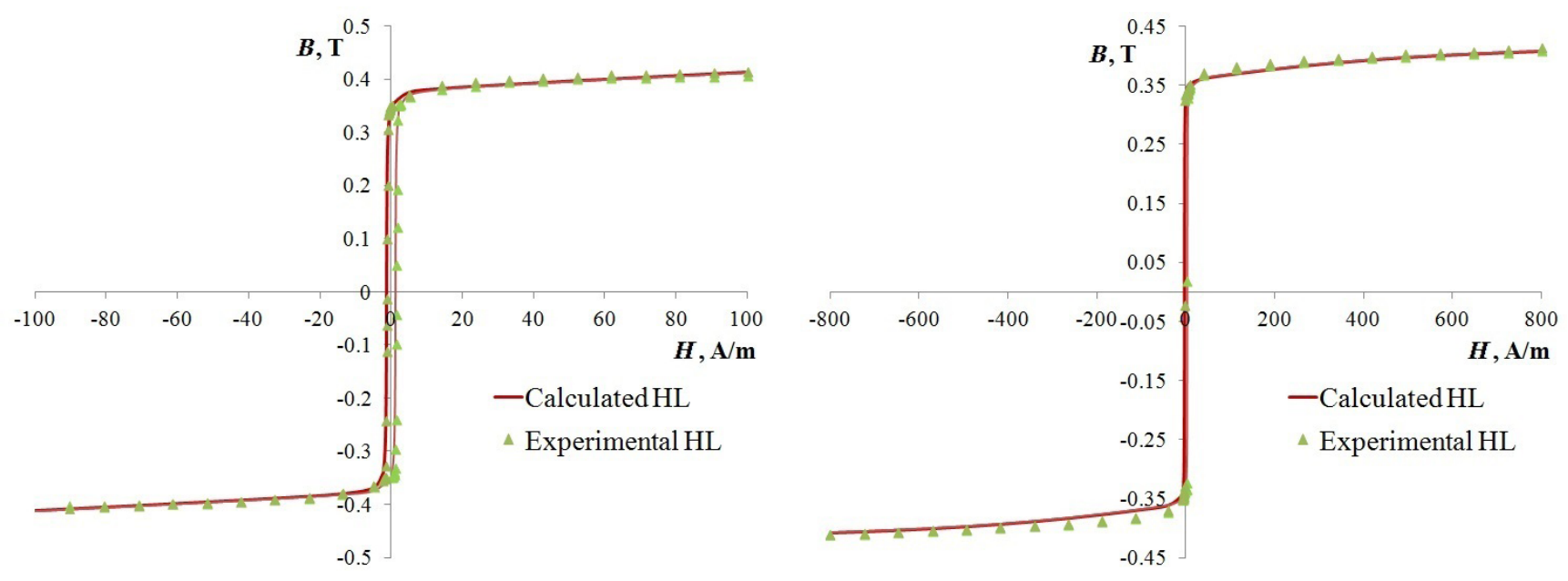

a

$\mathrm{b}$

Fig. 4. (Color online) Experimental and obtained by modelling the hysteresis loop of the amorphous $\mathrm{Co}_{68} \mathrm{Cr}_{4} \mathrm{Fe}_{4} \mathrm{Si}_{13} \mathrm{~B}_{11}$ alloy in a field of $100 \mathrm{~A} / \mathrm{m}(\mathrm{a})$ and $800 \mathrm{~A} / \mathrm{m}(\mathrm{b})$.

Table 2. Statistical characteristics of the obtained model HL-curves for various alloys.

\begin{tabular}{|c|c|c|c|c|}
\hline Alloy & $H_{m}, \mathrm{~A} / \mathrm{m}$ & $S_{r}^{2}, 10^{-4} \mathrm{~T}^{2}$ & $R^{2}$ & F-criterion \\
\hline \multirow{2}{*}{$\mathrm{Fe}_{56} \mathrm{Co}_{25} \mathrm{~B}_{14} \mathrm{Si}_{5}$} & 100 & 4 & 0.997 & 15100 \\
\cline { 2 - 5 } & 800 & 2 & 0.999 & 49128 \\
\hline \multirow{2}{*}{$\mathrm{Fe}_{77} \mathrm{Ni}_{1} \mathrm{Si}_{9} \mathrm{~B}_{13}$} & 100 & 2 & 0.998 & 49096 \\
\cline { 2 - 5 } & 800 & 4 & 0.992 & 7724 \\
$\mathrm{Co}_{68} \mathrm{Cr}_{4} \mathrm{Fe}_{4} \mathrm{Si}_{13} \mathrm{~B}_{11}$ & 100 & 7 & 0.995 & 7609 \\
\cline { 2 - 5 } & 800 & 16 & 0.986 & 2850 \\
\hline
\end{tabular}

out to be large enough to consider the applied model adequate.

The absolute error in the approximation of the induction values was from 0.027 to $0.038 \mathrm{~T}$, which is less than the error in measuring the magnetic induction on the MK-3E installation equal to $0.04 \mathrm{~T}$.

\section{Conclusions}

A model of the symmetric hysteresis loop in the form of analytical expressions for the descending and ascending branches of the loop is proposed. The induction value is presented as the sum of reversible and irreversible contributions. An irreversible contribution to induction is described by a modified linear fractional function with three parameters: residual induction, coercive force, and an additional parameter $B_{m 1}$, which characterizes the maximum attainable induction in a given field due to irreversible magnetization reversal processes. The reversible contribution is described by the Langevin function with two parameters: the characteristic field of reversible magnetization reversal $H_{\text {rev }}$ and the maximum induction $B_{m 2}$ attainable due to reversible magnetization.

The model provides the passage of the calculated curves through the points of residual induction and coercive force, and when selecting the parameters $B_{m 1}, B_{m 2}, H_{r e v}$ - through the tops of the hysteresis loop.

The adequacy of the proposed HL-model was established by comparing the theoretical and experimental branches of the hysteresis loop using the example of amorphous soft magnetic alloys $\mathrm{Fe}_{56} \mathrm{Co}_{25} \mathrm{~B}_{14} \mathrm{Si}_{5}, \mathrm{Co}_{68} \mathrm{Cr}_{4} \mathrm{Fe}_{4} \mathrm{Si}_{13} \mathrm{~B}_{11}$ and $\mathrm{Fe}_{77} \mathrm{Ni}_{1} \mathrm{Si}_{9} \mathrm{~B}_{13}$.

The resulting model makes it possible to achieve a sufficiently high quality of approximation of the magnetic induction values with an error not exceeding the measurement error, and its application does not require complex calculations or the development of a special computer program.

The advantage of the model can be considered the possibility of separating the reversible and irreversible contributions to the magnetic induction according to the experimental data.

\section{References}

1. S. Tikadzumi. Physics of Ferromagnetism: Magnetic Properties of Materials. Moscow, Mir (1987) 420 p. (in Russian) [С. Тикадзуми. Физика ферромагнетизма. Магнитные свойства вещества. Москва, Мир (1987) 420 с.]

2. A.V. Belokon, A.S. Scaliukh. Mathematical modelling of irreversible polarization processes. Moscow, Fizmatlit (2010) 325 p. (in Russian) [А. В. Белоконь, А. С. Скалиух. Математическое моделирование необратимых процессов поляризации. Москва, Физматлит (2010) $325 \mathrm{c.}]$

3. M.A. Krasnoselsky, A.V. Pokrovsky. Systems with hysteresis. Moscow, Nauka (1983) 275 p. (in Russian) [М.А. Красносельский, А.В. Покровский. Системы с гистерезисом. Москва, Наука (1983) 275 с.] 
4. I. D. Mayergoyz. IEEE Trans. Magn. 22 (5), 603 (1986). Crossref

5. G. Bertotti. Hysteresis in magnetism. San Diego, Academic Press (1998) 558 p. Crossref

6. E. Della Torre, L. H. Bennett. Discrete Contin. Dyn. Syst. Suppl. Vol., 854 (2005).

7. E. G. Korol. EiE. 6, 44 (2007). (in Russian) [Е. Г. Король. Электротехника и электромеханика. 6, 44 (2007).]

8. F. Preisach. Z. Phys. 94 (5-6), 277 (1935). Crossref

9. D. C. Jiles, D. L. Atherton. J. Magn. Magn. Mater. 61, 48 (1986). Crossref

10. A. B.Altman, A. N.Gerberg, P. A.Gladyshev.In:Permanent Magnets: A Handbook (Ed. by Yu. M. Pyatina). Moscow, Energiya (1980) 488 p. (in Russian) [А.Б. Альтман,
А.Н. Герберг, П.А. Гладышев. Постоянные магниты: Справочник (под ред. Ю.М. Пятина). Москва, Энергия (1980) 488 с.]

11. J.H. Chan, A. Vladimirescu, X.-C. Gao, P. Liebmann., J. Valainis. IEEE Trans. Comput.-Aided Design Integr. Circuits Syst. 10 (4), 476 (1991). Crossref

12. V.Yu. Vvedenskiy, G.A. Nuzhdin, S. V. Frolov. Sborka v mashinostroenii, priborostroenii. 10, 471 (2019). (in Russian) [В. Ю. Введенский, Г. А. Нуждин, С. В. Фролов. Сборка в машиностроении, приборостроении. 10, 471 (2019).]

13. V. Yu. Vvedenskiy, I. B. Kekalo. Phys. Met. Metallogr. 4, 99 (1992). (in Russian) [В. Ю. Введенский, И.Б. Кекало. ФМM. 4, 99 (1992).] 